\title{
Huntingtin Protein Measurement
}

National Cancer Institute

\section{Source}

National Cancer Institute. Huntingtin Protein Measurement. NCI Thesaurus. Code

C142279.

The determination of the amount of hunting tin protein present in a sample. 